\title{
Determines The Height Based On The Length Of The Middle Finger (digiti III Manus)
}

\author{
Hendra Aprialdi Saputra, Alfred C. Satyo, Abdul Gafar Parinduri \\ Department of Forensic and Medicolegal of Faculty of Medicin Universitas Sumatera Utara \\ DOI: 10.29322/IJSRP.11.02.2021.p11044 \\ http://dx.doi.org/10.29322/IJSRP.11.02.2021.p11044
}

\begin{abstract}
Various kinds of events such as mass disasters or mutilated murders can cause a person's limbs to be unrecognized and even pieces of his body separated. If this is the case, the estimation of height is a major step in the process of identifying the unknown person. Research on the fingers is important to do to determine a person's identity because a body piece that is found is not always in the form of a long bone, it can also be found in the form of a short cut like a finger. Objective: This study aims to determine the relationship between the length of the middle finger and the height of the residents of Perumahan Citra Wahana I in Deli Serdang Regency. Method: The study design was correlative analytic with cross-sectional approach. The population of this study were male and female citizens aged 21 to 45 years who live in Perumahan Citra Wahana I of Deli Serdang Regency and meet the inclusion and exclusion criteria. A sample of 63 people was determined using the total sampling method. Results: Middle finger length had a positive and significant correlation with height where the correlation coefficient was in the range of 0.780 to 0.939 $(\mathrm{p}<0.001)$. The linear regression equation obtained shows that the Standard Error of the Estimate (SEE) ranges from 1.714 to 3.528 ( $\mathrm{p}<0.001$ ). Conclusion: There is a significant relationship between the length of the middle finger (digiti III manus) and the height of the residents of Perumahan Citra Wahana I in Deli Serdang Regency accompanied by a significant to very significant correlation coefficient, and thus height can be estimated by measuring the length of the middle finger by the linear regression equation.
\end{abstract}

Index Terms- length of the middle finger, height, linear regression equation, anthropometry

\section{INTRODUCTION}

\section{$\mathrm{V}$} Background

arious kinds of incidents can cause a person's limbs to be unrecognized or his body fragments scattered, such as mass disasters and accidents, murders, mutilations or fires that can make the victim's body unrecognizable, damaged, even charred so that his identity is unknown.

Mass disasters can be caused by both nature and humans and cause many casualties. Indonesia's natural conditions play an important role in disaster risk. Indonesia is located in the Southeast Asian archipelago consisting of 17,000 islands and 1.9 million $\mathrm{km}^{2}$ of land. The area of Indonesian waters reaches 5.8 million with a coastline of more than $80,000 \mathrm{~km}$. Indonesia is surrounded by the Pacific and Indian Oceans and is located between 2 continents, namely the Australian Continent in the South and the Asian Continent in the North. Geographically, Indonesia is flanked by 3 major world plates, namely the Indo-Australian Plate, the Eurasian Plate and the Pacific Plate. This condition provides an indication that Indonesia is at high risk of experiencing natural disasters such as earthquakes, landslides, floods, tsunamis, as well as accidents on land, sea and air.

The National Disaster Management Agency (BNPB) recorded 2,341 disasters in 2017, with details of the 3 most occurrences being floods (787), tornadoes (716), and landslides (614). The rate of disaster is affected by weather and runoff. Data from the Meteorology, Climatology and Geophysics Agency (BMKG) during 2017 to 20 December 2017 revealed that there had been 6,893 earthquakes, where earthquakes with a strength of more than 5 on the Richter scale (RS) were 208 times. The most recent incident that rocked Indonesia's territory was an earthquake in Lombok with a magnitude of 7.0 on August 5, 2020 which was accompanied by hundreds of aftershocks after that. Meanwhile, of the 127 volcanoes in Indonesia, there are 2 volcanoes with Alert status and eruptions, namely Mount Sinabung and Mount Agung. North Sumatra Province is one of the areas that is very at risk of natural disasters. This is evidenced by the number of natural disasters that occurred up to 493 incidents where floods dominated as many as 299 incidents from 2015 to 2016. Meanwhile, on June 18, 2020 the sinking of the Sinar Bangun Motor Ship in the waters of Lake Toba of North Sumatra which was caused by excess passenger capacity resulted in many victims missing and dying.

Apart from the above incidents, another case where the victim's body was cut into pieces was murder accompanied by mutilation. Generally, the killer aims to remove traces of him and the victim's identity. The main problem that complicates the identification process is when the victim's body is cut into small pieces and this is very difficult to do if it only relies on visual examination, so in this case a forensic identification will be needed. The number of mutilation cases recorded by the Public Relations of the National Police in 2011 occurred as many as 12 cases and increased in 2012 with 18 cases. In 2016, cases of murder accompanied by mutilation increased by $16.41 \%$ to 78 cases where in the previous year there were 67 cases.

In a 2017 criminal statistical study by the Central Bureau of Statistics, it was revealed that in the last five years the number of incidents of crimes against life in Indonesia tended to fluctuate. North Sumatra Province is listed as the province with the highest number of crimes against life, with 161 incidents in 2016 with more than 100 murder cases. 
Due to various cases that have occurred and the development of science, there have been many studies regarding the estimation of height based on certain bone lengths. Basically, every human being has a different body shape. There is also a difference between the length of one body part and another. This is because every part of the body is unique and has the possibility of defining a biological correlation. The existence of these differences can be used in determining a person's identity. Determination of a person's identity can be carried out for both living and deceased people. Forensic anthropometry plays an important role in formulating a biological profile that involves determining height, sex, ethnicity and nation as well as age so that it can provide a simple identification for a person. Height is an important anthropometric parameter. In general, height plays a role in determining the Body Mass Index (BMI), nutritional status, basal energy needs, and the stages of testing in human resource recruitment such as admission to the Police, even for medicolegal purposes.

Estimation of height is also a major step in the process of identifying an unknown person, especially victims of mass disasters or mutilated murders where only partial or mutilated body parts are found. Thus, the estimation of a person's height becomes a parameter that is needed in anthropological studies and forensic identification.

Estimation of height can be made based on other body parts, such as the following bones: humerus, radius, ulna, femur, tibia, fibula, phalange, sternum, nose height, calcaneus, and footprints. Several studies regarding the estimated height have been conducted at the Faculty of Medicine, University of North Sumatra, namely the metacarpal bones, ulna bones and tibia bones.

Research on the estimation of height based on long bones has been done a lot, but this is not the case with short bones which is still rarely done in Indonesia. While abroad, research on the measurement of short bones such as the fingers is not uncommon. This research on fingers is important to do to determine a person's identity because pieces of bodies found such as in medicolegal cases or disaster incidents are not always in the form of long bones, they can also only be short pieces such as fingers found.

Based on the results of research conducted by Fatati (2013) regarding the correlation between height and finger length, it was found that there was a significant relationship between height and length of 3 fingers, namely the index finger, middle finger and ring finger with the most significant correlation was found in middle finger. Likewise with research conducted by Putri (2017) on the correlation of the length of the index finger bone (digit II manus) with the height of adult males of Balinese and Batak tribes in Tanjung Senang, Bandar Lampung, with a total sample of 35 men aged 21-45 years that found a moderate correlation between index finger bone length and height.

In India, a study was conducted on the relationship between finger length and height and the results found were that there was a more significant correlation in men than in women. This is similar to the study of the middle finger as a determinant of height carried out in the Indian population with a sample of 500 students aged 20-30 years and the results obtained are that the height of men is more significant than women. Meanwhile, the only research on the relationship between middle finger length and height in Indonesia was conducted by Mirza (2013) who found that there was a relationship between middle finger length and height.

However, there are differences in the average height in each of the previous studies. This is because height is influenced by the interaction of genetic factors and environmental factors. According to the Hardy-Weinberg balance law, height is inherited continuously from generation to generation. Genetic factors that come from parents are permanent through the father's lineage to biological children and affect the ethnicity of an individual. This causes ethnicity to be classified as a factor that affects height.

Indonesia has various ethnic groups, one of which is the Batak tribe with the third largest population after the Javanese and Sundanese, which is $3.58 \%$ with its main area located in North Sumatra Province. There are eight ethnic groups or indigenous tribes who mingle in North Sumatra Province plus the presence of immigrant tribes such as Javanese, Minang, Acehnese, including Indian and Chinese ethnicities. Even so, the Batak tribe, which consists of six sub-tribes such as Toba, Mandailing, Karo, Simalungun, Pak-pak, and Angkola Sipirok, is the largest tribe that occupies the North Sumatra region, amounting to $44.75 \%$.

Apart from race factors, age also affects height growth, especially in bone classification. Height growth reaches its peak in adolescence, which is around 12-16 years, then it will slow down at the age of 18-20 years due to the fusion of the epiphyseal plate. The center of calcification at the tip of the bone or the socalled "Epiphyse Line" will end with age and fusion of the plates occurs on average up to the age of 21 years in each bone. Bone growth that continues under the age of 21 will cause studies to be biased if research is carried out at that age.

Until now, research on the relationship between middle finger length and height in Indonesia is still rare. Thus, the researcher is interested in conducting research on determining height based on the length of the middle finger (digiti III manus) in the residents of Perumahan Citra Wahana of Pancur Batu, Deli Serdang Regency.

\section{Problem Formulation}

Based on the background above, the problem formulation in this research is whether there is a relationship between the length of the middle finger (digiti III manus) and the height of the residents of Perumahan Citra Wahana of Pancur Batu, Deli Serdang Regency.

\section{Research Objectives \\ General objective}

To determine the relationship between the length of the middle finger (digiti III manus) and the height of the residents of Perumahan Citra Wahana Phase 1 of Pancur Batu, Deli Serdang Regency.

\section{Specific objectives}

The specific objectives of this research are:

1. To determine the average height of the residents of Perumahan Citra Wahana of Pancur Batu, Deli Serdang Regency.

2. To determine the average length of the middle finger (digiti III manus) of residents of Perumahan Citra Wahaan of Pancur Batu, Deli Serdang Regency. 
3. To analyze the relationship between height and middle finger length (digiti III manus) based on gender in residents of Perumahan Citra Wahana of Pancur Batu, Deli Serdang Regency. 4. To analyze the relationship between the length of the middle finger (digiti III manus) and the height of the residents of Perumahan Citra Wahana of Pancur Batu, Deli Serdang Regency. 5. To find the regression formula for the relationship between the length of the middle finger (digiti III manus) and the height of the residents of Perumahan Citra Wahana of Pancur Batu, Deli Serdang Regency.

\section{Hypothesis}

There is a relationship between the length of the middle finger (digit III manus) and the height of the residents of Perumahan Citra Wahana of Pancur Batu, Deli Serdang

\section{RESULTS AND DISCUSSION}

\section{Results}

The study was conducted on 16 to 22 July 2020 in Perumahan Citra Wahana of Pancur Batu, Deli Serdang Regency. The data obtained were then collected and processed through the editing, coding, entry, cleaning, and saving processes. Furthermore, the data were analyzed in two stages. The first stage is a univariate analysis to produce the distribution of frequencies, percentages and mean values of the dependent and independent variables. The second stage is bivariate analysis to determine the relationship between the two variables.

\section{Univariate Analysis}

The frequency distribution of sex 
Table 1 The frequency distribution of sex

\begin{tabular}{lll}
\hline Sex & Frequency & Percentage $(\%)$ \\
\hline Male & 21 & 33.3 \\
Female & 42 & 66.7 \\
\hline Total & $\mathbf{6 3}$ & $\mathbf{1 0 0}$ \\
\hline
\end{tabular}

Based on the table above, it is found that the frequency of subjects who are male is 21 $(33.3 \%)$ and female is $42(66.7 \%)$.

\section{The frequency distribution of age}

Table 2 The frequency distribution of age

\begin{tabular}{lll}
\hline Age (year) & Frequency & Percentage $(\%)$ \\
\hline $21-25$ & 50 & 79.4 \\
$26-30$ & 6 & 9.5 \\
$31-35$ & 2 & 3.2 \\
$36-40$ & 2 & 3.2 \\
$41-45$ & 3 & 4.8 \\
\hline Total & $\mathbf{6 3}$ & $\mathbf{1 0 0}$ \\
\hline
\end{tabular}

Based on the table above, it is found that the frequency of subjects aged 21-25 years are 50 $(79.4 \%)$, aged $26-30$ years old are $6(9.5 \%)$, aged $31-35$ years are $2(3.2 \%)$, aged $36-40$

\section{The measurement result of the right middle finger}

Table 3 The measurement result of the right middle finger

\begin{tabular}{ll}
\hline Sex & Mean (standard deviation) \\
\hline Male & $7.508(0.362)$ \\
Female & $6.889(0.304)$ \\
\hline Overall & $7.096(0.435)$ \\
\hline
\end{tabular}

years are $2(3.2 \%)$, and aged $41-45$ years are $3(4.8 \%)$.
Table 3 shows that the mean length of the right middle finger for men is $7.508 \mathrm{~cm}$ and for women it is $6.889 \mathrm{~cm}$, while the mean length of the right middle finger for the whole is $7.096 \mathrm{~cm}$.

\section{The measurement result of the left middle finger}

Tabel 4 The measurement result of the left middle finger 


\begin{tabular}{ll}
\hline Sex & Mean (standard deviation) \\
\hline Male & $7.592(0.430)$ \\
Female & $6.854(0.381)$ \\
\hline Overall & $7.100(0.528)$ \\
\hline
\end{tabular}

Table 4 shows that the mean length of the left middle finger for men is $7.592 \mathrm{~cm}$ and for women is $6.854 \mathrm{~cm}$, while the mean length of the left middle finger as a whole is $7.100 \mathrm{~cm}$.

\section{Results of height measurements}

Table 5 Results of height measurements

\begin{tabular}{ll}
\hline Sex & Mean (standard deviation) \\
\hline Male & $166.079(5.519)$ \\
Female & $155.070(3.804)$ \\
\hline Overall & $158.860(6.823)$ \\
\hline
\end{tabular}

Table 5 shows that the mean height for men is $166.079 \mathrm{~cm}$ and that for women is $155.070 \mathrm{~cm}$, while the mean height for the whole is $158.860 \mathrm{~cm}$.

\section{Bivariate Analysis}

\section{Normality test}

The normality test of the measurement results needs to be done first to determine the correlation test to be used. The normality test among numerical variables consists of the Kolmogorov-Smirnov test recommended for large samples (more than 50) and the Shapiro-Wilk test for small samples (less or equal to 50).

The normality test will produce a Value of $p$ that can determine whether or not the data is normally distributed. If the value of $\mathrm{P}>0.05$ is obtained for a variable, it means that the data is normally distributed. Conversely, if the value of $\mathrm{P}<0.05$, the data are not normally distributed.

The results of the normality test for each variable are as follows:

Table 6. Results of normality test

\begin{tabular}{|c|c|c|c|c|c|}
\hline & \multirow{2}{*}{ Sex } & \multirow{2}{*}[2]{} & \multirow{2}{*}{ Variable } & \multirow{2}{*}{$\begin{array}{l}{[3]} \\
{[4]}\end{array}$} & Kolmogorov-Smirnov \\
\hline & & & & & $\mathbf{P}$ \\
\hline & Male & [6] & right middle finger & [7] & 0.200 \\
\hline [8] & & & left middle finger & [10] & 0.200 \\
\hline [11] & & [12] & height & [13] & 0.200 \\
\hline [14] & Female & {$[15]$} & right middle finger & [16] & 0.200 \\
\hline [17] & & [18] & left middle finger & [19] & 0.064 \\
\hline [20] & & [21] & height & [22] & 0.200 \\
\hline [23] & Overall & [24] & right middle finger & [25] & 0.200 \\
\hline [26] & & [27] & left middle finger & [28] & 0.200 \\
\hline [29] & & [30] & height & [31] & 0.011 \\
\hline
\end{tabular}

Based on table 4.6, it appears that only one variable is not normally distributed, namely height for the whole with a value of $\mathrm{P}=0.011$ $(\mathrm{P}<0.05)$, while the other variables are normally distributed.

\section{Linearity test}

Linearity test is used to determine whether the data can be tested by correlation test. The 
relationship between two linear data can be tested with a correlation test, while for those that are not linear, a correlation test is not carried out.

The linearity assumption is checked by making a scatter graph. According to the statistical book by Sopiyudin (2014), data distribution has a linear impression if a relationship follows a straight line pattern which can be seen through the scatter graph. Linear can have a positive or negative direction. Positive linear means that the greater the value of a variable, the higher the value of other variables. In contrast to negative linearity, the higher the value of a variable, the lower the value of other variables.

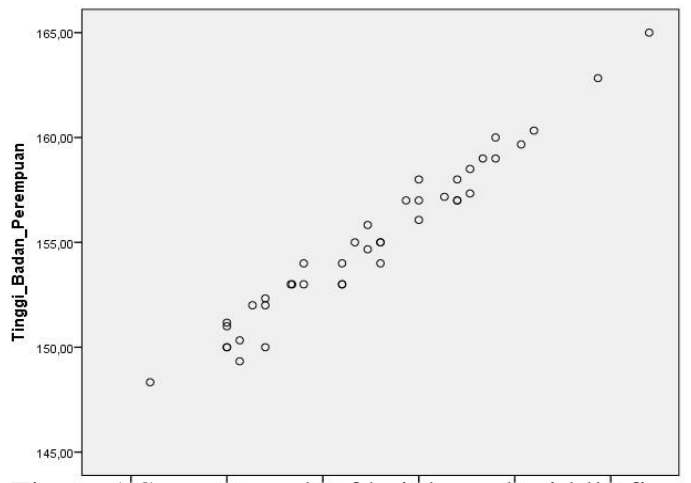

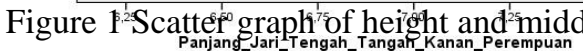

Figure 1 shows a scatter graph between height and middle finger of the male. The relationship between height and right middle finger of men has a positive linear

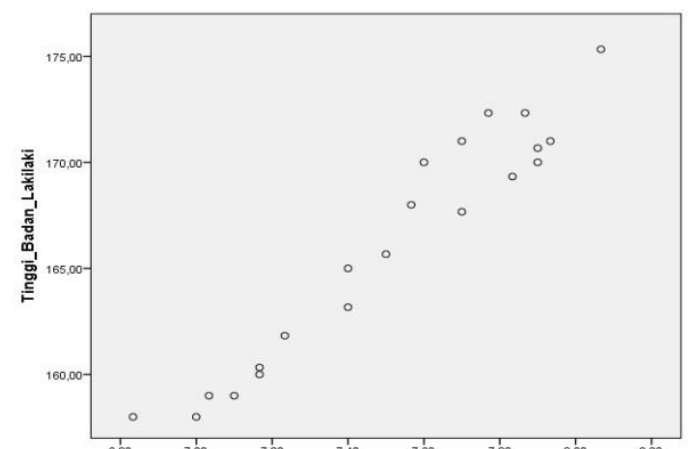

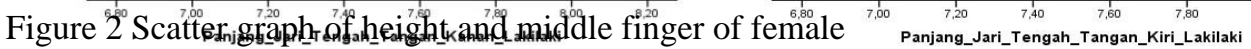

Figure 2 shows a scatter graph of the height and middle finger of the female. The relationship between height and right middle finger of women has a positive linear

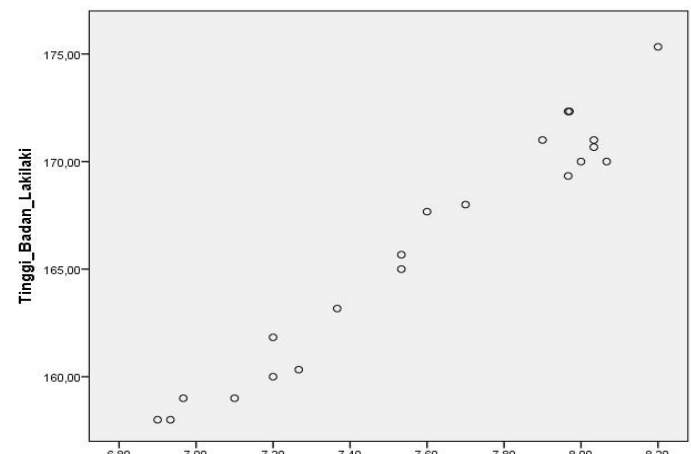

relationship and the relationship between

height and left middle finger of men also has a positive linear relationship.

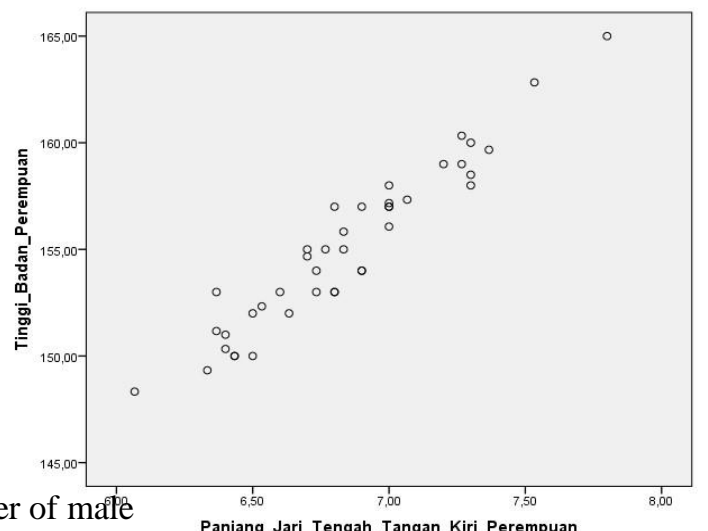

impression and the relationship between height and left middle finger of women also has a positive linear impression. 


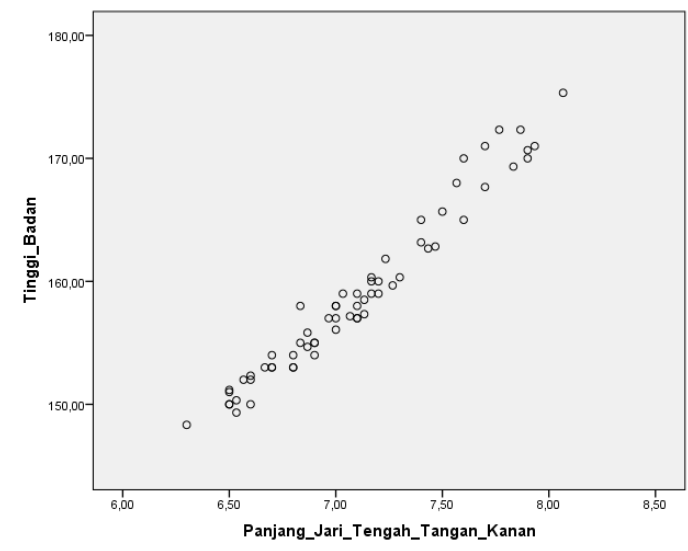

Figure 3 Scatter graph of height and middle finger

Figure 3 shows a scatter graph of height and middle finger for the whole. The relationship between height and right middle finger has a positive linear impression and the relationship between height and left middle finger also has a positive linear impression. Based on the graphs shown in Figures 1, 2, and 3 it can be concluded that all the relationships between height and middle finger length are positive linear. Thus the data analysis can be continued to the correlation test.

\section{Correlation test}

The correlation test between numerical variables where one of them is normally distributed is the Pearson test, while the correlation test between numerical variables that is not normally distributed is the Spearman test. After the normality test and linearity test are carried out, the correlation test that can be used in this research is the Pearson test because one of the variables is normally distributed and the linearity requirements are met.

The things that are included in the interpretation of the correlation test are the Table 7 The relationship between the length of the right middle finger and height

\begin{tabular}{llll}
\hline Sex & Number & Pearson Correlation $(\mathbf{r})$ & P \\
\hline Male & 21 & 0.866 & $<0.001$ \\
Female & 42 & 0.902 & $<0.001$ \\
Overall & 63 & 0.939 & $<0.001$ \\
\hline
\end{tabular}

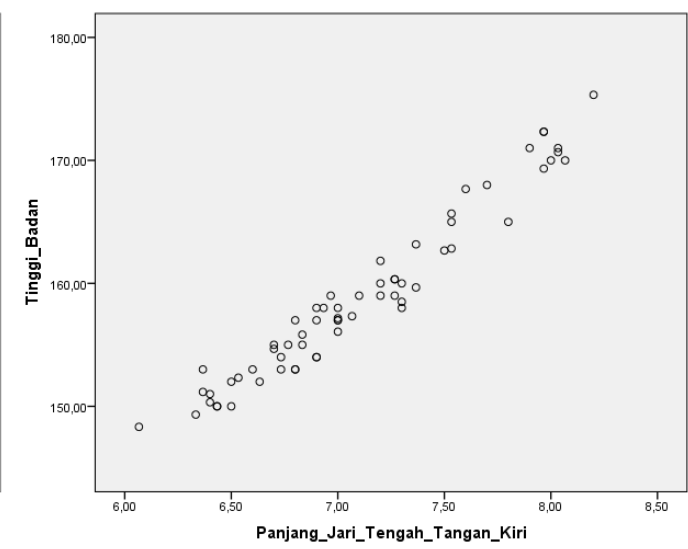

statistical strength of the correlation, the direction of the correlation, the p-value, and the clinical significance. The strength of correlation is called very low if the value is 0.0 to $<0.2$, low if the value is 0.2 to $<0.4$, moderate if the value is 0.4 to $<0.6$, high if the value is 0.6 to $<0.8$, and very high when the value is 0.8 to 1 . The direction of correlation can be seen through the scatter graph in the linearity test which has a positive $(+)$ or negative (-) value. Based on the value of $\mathrm{p}$, if $\mathrm{p}<0.05$ means that there is a significant correlation between the two variables tested, on the contrary, if $p>0.05$ means that there is no correlation between the two variables. And for clinical significance, if the value obtained is $<$ minimal $\mathrm{r}(0.00)$ it means that the correlation between variables is not significant, conversely, if the value obtained is $>$ minimal $r(0.00)$ it means that the correlation between variables is significant.

The relationship between the length of the middle finger and the height of the subjects is obtained as follows: 
Table 7 shows that the relationship between the length of the right middle finger and height in men has a correlation coefficient value of $0.866(\mathrm{p}<0.001)$, the direction of positive correlation $(+)$, and the value obtained is > minimal $\mathrm{r}$. The relationship between the length of the right middle finger and height in women has a correlation coefficient value of 0.902 ( $\mathrm{p}<0.001)$, the direction of the correlation is positive $(+)$, and the value obtained is $>$ minimal $r$. The relationship between the length of the right middle finger and height for the whole subject has a correlation coefficient of 0.939 ( $\mathrm{p}<0.001)$, the direction of the correlation is positive (+), and the value obtained is $>$ minimal $r$.

Table 8 The relationship between the length of the left middle finger and height

\begin{tabular}{llll}
\hline Sex & Number & Pearson Correlation (r) & P \\
\hline Male & 21 & 0.784 & $<0.001$ \\
Female & 42 & 0.780 & $<0.001$ \\
Overall & 63 & 0.858 & $<0.001$ \\
\hline
\end{tabular}

Table 8 shows that the relationship between the length of the left middle finger and height in men has a correlation coefficient value of $0.784(\mathrm{p}<0.001)$, the direction of positive correlation $(+)$, and the value obtained is $>$ minimal $r$. The relationship between the length of the left middle finger and height in women has a correlation coefficient of 0.780 $(\mathrm{p}<0.001)$, the direction of the correlation is positive (+), and the value obtained is > minimal $r$. The relationship between the length of the left middle finger and height for the whole subject has a correlation coefficient value of $0.858(\mathrm{p}<0.001)$, the direction of the positive correlation $(+)$, and the value obtained is $>$ minimal $r$.

\section{Linear regression analysis}

Next is the estimate of height by middle finger length obtained through linear regression analysis. The regression analysis will produce an equation that can connect the dependent variable with the independent variable. Linear regression is used if the independent variable is a numeric variable. The variables that can be included in the linear regression analysis are those that in the correlation test have a value of $\mathrm{p}<0.05$. All correlation test results have a value of $\mathrm{p}<$ 0.001 ( $\mathrm{p}<0.05$ ) so that all data can be included in the linear regression analysis.

Table 9 The results of the linear regression analysis test

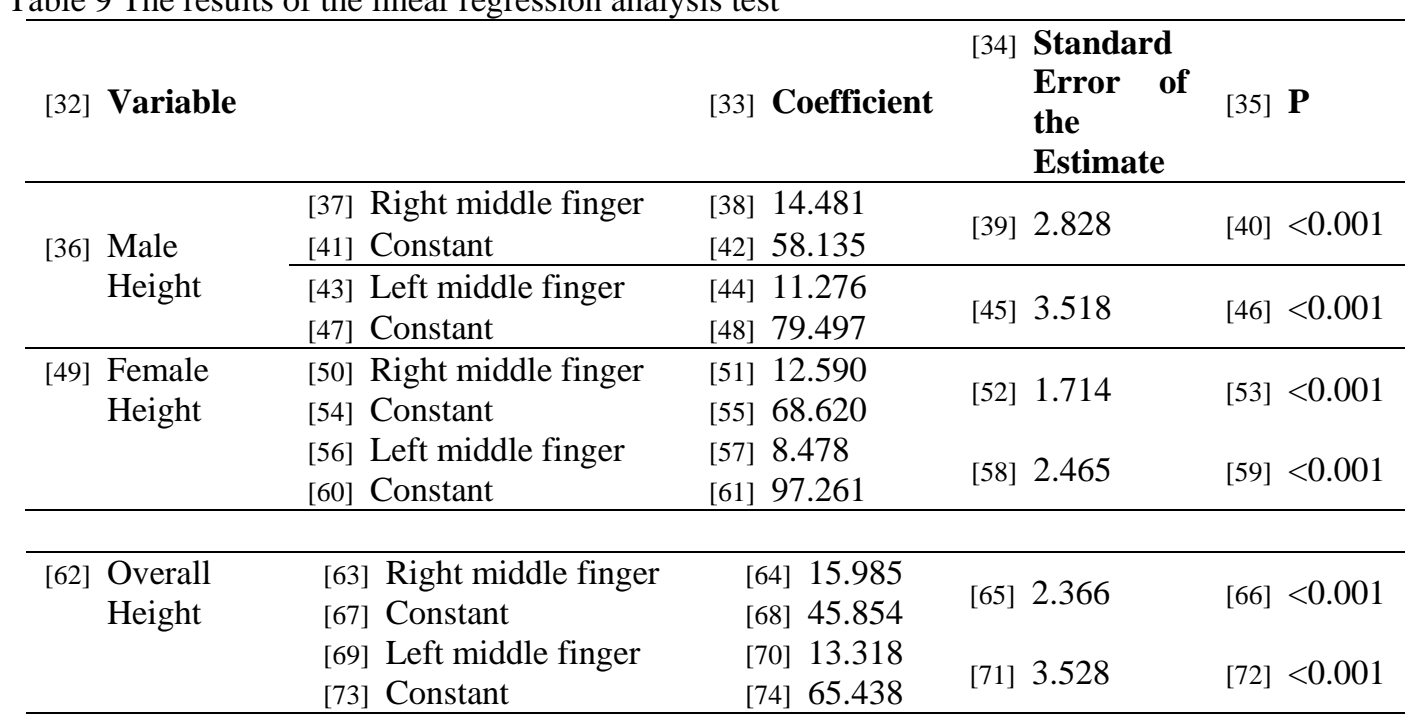


Based on the results of linear regression analysis in Table 9, a linear regression equation can be formulated based on:

$$
\begin{array}{lll}
\mathrm{y}=\mathrm{a}+\mathrm{bx} & \\
\text { where: } & \\
\mathrm{Y} & = & \text { Dependent variable } \\
\mathrm{a} & = & \text { Constant } \\
\mathrm{b} & = & \text { Coefficient of independent } \\
& & \text { variable } \\
\mathrm{x} & = & \text { Independent variable }
\end{array}
$$

Thus, the correlation between middle finger length and height is obtained through the linear regression equation as follows:

1. In male subjects

a. Male height $(\mathrm{cm})=58.135+14.481 \mathrm{x}$ right middle finger length $(\mathrm{cm})$

b. $\quad$ Male height $(\mathrm{cm})=79.497+11.276 \mathrm{x}$ left middle finger length $(\mathrm{cm})$

2. In female subjects

a. Female height $(\mathrm{cm})=68.620+12.590 \mathrm{x}$ right middle finger length $(\mathrm{cm})$

b. Female height $(\mathrm{cm})=97.261+8.478 \mathrm{x}$ left middle finger length $(\mathrm{cm})$

3. In the whole subject

a. Height $(\mathrm{cm})=45.854+15.985 \mathrm{x}$ right middle finger length $(\mathrm{cm})$

b. Height $(\mathrm{cm})=65.438+13.318 \mathrm{x}$ left middle finger length $(\mathrm{cm})$.

\section{DISCUSSION}

The sample in this study consisted of 21 men and 42 women. The number of women is more than men because in this population the number of women is more dominant than men. Most of the subjects in the study sample belonged to the 21-35 year age group because residents aged 21 years, especially those aged 35 years, currently dominate the resident population of Perumahan Citra Wahana of Pancur Batu, Deli Serdang Regency. In addition, the inclusion criteria of this study were residents of Perumahan Citra Wahana of Pancur Batu, Deli Serdang Regency, from the ages of 21 to 45 years.

From the results of the study, it was found that the average length of the right and left middle fingers in men was longer than in women. It was also found that the average height of men was higher than that of women. This is consistent with research conducted on medical students of the University of Syiah Kuala, medical students of class 2013 at the University of Sam Ratulangi, Indian population in Manipal, Nigerian population, and 2017 research on medical students of Muhammadiyah University of North Sumatra.

The difference in average height between men and women is due to the different growth rates of men and women. At around the age of 10, the growth rate for boys and girls tends to be the same. However, after the age of 12 the growth rate of boys tends to be faster than girls, this is why most boys who reach adolescence are higher than girls. This gender difference is also related to the age of puberty, where the age of puberty in boys is two years longer than in girls so that they have a longer time to grow. So it is theoretically stated that adult men are taller, have longer and heavier legs, and larger and denser muscle mass than adult women. The male sample in this study had an average size of the left middle finger that was longer than the right middle finger. This is in contrast to the results in the sample of women who had an average size of the right middle finger that was longer than the left middle finger. The results of this measurement are consistent with research conducted on medical students at the University of Syiah Kuala and the Indian population in Manipal.

The difference in the mean length of the right and left middle finger in both men and women in this study was not significant. As for anthropometric studies, it is found that the part of the measurements obtained from the right side is different from the left side. This difference between right and left in individuals is known as asymmetry. Asymmetric limbs can occur spontaneously and are not associated with musculoskeletal pathologies. Generally, the upper limb displays a greater degree of asymmetry than the lower limb.

The correlation between middle finger length and height has a high $(0.780-0.784)$ to very high $(0.858-0.939)$ correlation. These results are consistent with the research conducted on the Indian population in Manipal, but different from the research conducted at Airlangga University, where the moderate correlation between middle finger length and height was found in this study. Meanwhile, research conducted at the University of Syiah Kuala indicated a moderate to high correlation for men and women. The length of the middle finger shows an accurate correlation coefficient value to show that the length of the middle finger has a significant relationship with height so that it can be used as a source of measuring tools for height estimation. Previous research has also shown that middle finger length is the most accurate measurement for estimating height compared to other finger lengths.

Estimation of height can be made by finding a special regression. This research has found a linear regression equation that can be used to estimate the height by the length of the middle finger. This equation has a Standard Error of the Estimate (SEE) which ranges from 1.714 to 3.528 . SEE is a good parameter to show the relationship between the original value and the estimated value. The accuracy of the linear regression equation is indicated by the smaller the SEE value. The female sample had the lowest SEE value $(1,714-2,465)$, this indicates that the linear regression equation in the female sample shows a more accurate result. These 
results are consistent with research conducted on the Indian population in Manipal and research at the Syiah Kuala University. The difference in body proportion between one population and another is influenced by various factors. These factors are both internal, such as genetic, ethnic, racial, and gender factors, and external, including the environment, nutrition, socio-economic, and physical activity. This is why the linear regression equation for one population may not be applicable to another population and therefore a different linear regression equation must be found for each population to provide the most accurate results.

\section{CONCLUSIONS}

The results of the study indicate that there is a significant relationship between the length of the middle finger (digiti III manus) and the height of the residents of Perumahan Citra Wahana of Pancur Batu, Deli Serdang Regency, with a high to very high correlation coefficient. Thus, height can be estimated by measuring the length of the middle finger through the linear regression equation as follows:

1. Male height and middle finger length:

a) Male height $(\mathrm{cm})=58.135+14.481 \mathrm{x}$ length of right middle finger $(\mathrm{cm})$

b) Male height $(\mathrm{cm})=79.497+11.276 \mathrm{x}$ length of left middle finger $(\mathrm{cm})$

2. Female height and middle finger length:

a) Female height $(\mathrm{cm})=68.620+12.590 \mathrm{x}$ length of right middle finger $(\mathrm{cm})$

b) Female height $(\mathrm{cm})=97.261+8.478 \times$ length of left middle finger $(\mathrm{cm})$

3. Overall height and middle finger length:

a) Height $(\mathrm{cm})=45.854+15.985 \mathrm{x}$ length of right middle finger $(\mathrm{cm})$

b) Height $(\mathrm{cm})=65.438+13.318 \times$ length of left middle finger $(\mathrm{cm})$

\section{REFERENCES}

[1] Agrawal J, Raichandani L, Kataria S, Raichandani S. Estimation of Stature from Hand Length and Length of Phalanges. Journal of Evolutionof Medical and Dental Science. 2013.

[2] Amir A. Rangkaian Ilmu Kedokteran Forensik. Edisi Kedua. Medan: Bagian Ilmu Kedokteran Forensik dan Medikolegal Fakultas Kedokteran USU; 2010 ..

[3] Asmiliaty H. Model Prediksi Tinggi Badan untuk Kelompok Usia Dewasa Muda dengan Menggunakan Prediktor Panjang Depa di Fakultas Kesehatan Masyarakat. Depok: Fakultas Kesehatan Masyarakat Universitas Indonesia. 2012.

[4] Barut C., Sevinc O., Sumbuloglu V. Evaluation of Hand Asymetry inRelation to Hand Preference.CollAntropol. 2011.

[5] Byers S. Basics of Human Osteology and Odontology. In: Introduction to Forensic Anthropology. Third Ed. Boston; 2008.

[6] Buku Saku Tanggap Tangkas Tangguh Menghadapi Bencana. Edisi 2017. Jakarta: Pusat Data, Informasi dan Humas Badan Nasional Penanggulangan Bencana; 2020.

[7] C Sugianto OS, Mexitalia M. Perbandingan Tinggi Badan dan Rentang Tangan pada Anak Balita Usia 1-5 Tahun. Medica Hospitalia 2016;4(November 2016)

[8] Dahlan MS. Statistik untuk Kedokteran dan Kesehatan. Ed.6. Jakarta: Epidemiologi Indonesia; 2014.

[9] Devison R. Penentuan Tinggi Badan Berdasarkan Panjang Lengan Bawah. Medan: Fakultas Kedokteran Universitas Sumatera Utara. 2009.
[10] Fatati A. Korelasi antara Tinggi Badan dan Panjang Jari Tangan. Surabaya: Universitas Airlangga.

[11] Ferreira R. Importance of The Comparative Anatomy in Forensic Anthropology - Case Report. Case Report Article Importance. 2013;10(2):193-197.

[12] Habib SR, Kamal NN. Stature Estimation From Hand And Phalanges Lengths of Egyptians. Journal of Forensic and Legal Medicine. 2010.

[13] Harianto R. Buku Ajar Kesehatan Kerja. Jakarta: EGC; 2013.

[14] Honandar B., Tanudjaja G., Kaseke MM. Hubungan Tinggi Badan dan Panjang Tulang Ulna pada Etnis Sanghie Dewasa di Madidir Ure. Manado: Fakultas Kedokteran Universitas Sam Ratulangi. 2013.

[15] Idries AM, Tjiptomarnoto AL. Penerapan Ilmu Kedokteran Forensik Dalam Proses Penyidikan. Edisi Revisi. Jakarta: Sagung Seto; 2011.

[16] In Brief: Forensic Identification Of Human Remains. International Committee of the Red Cross; 2013.

[17] Kanchan T, Krishan K. Personal Identification in Forensic Examinations.Anthropol.

[18] KaradayiB.,KayaA.,AfsinH.PredictiveRoleof hand andFootDimensions in StatureEstimation. Romanian SocietyofLegalMedicine. 2012.

[19] Kumar L, Agarwal S, Garg R, Dixit AP. Correlation between Index Finger and Stature in Uttarakhand Population. Anthropol. 2014.

[20] Medika M. Perbandingan Korelasi Penentuan Tinggi Badan antara Metode Pengukuran Panjang Tibia Perkutaneus dan Panjang Telapak Kaki.Mutiara Medika. 2011.

[21] Mirza R. Penentuan Tinggi Badan Berdasarkan Panjang Jari Tengah pada Mahasiswa Fakultas Kedokteran Angkatan 2009 - 2012. ETD Unsyiah. 2013

[22] Moore KL, Dalley II AF, Agur AMR, Moore ME. Anatomi Berorientasi Klinis. Fifth Ed. (Astikawati R, ed.). Jakarta: Erlangga; 2013.

[23] Notoadmodjo S. Metodologi Penelitian Kesehatan. Jakarta: Rineka Cipta 2010

[24] Paulsen F, Waschke J. Sobotta: Atlas Anatomi Manusia Jilid I. Jakarta: EGC 2013.

[25] Prawestiningtyas E, Algozi AM. Forensic Identification Based on Both Primary and Secondary Examination Priority in Victim Identifiers on Two Different Mass Disaster Cases. Jurnal Kedokteran Brawijaya. 2009.

[26] Poluan B, Kristanto EG. Hubungan Tinggi Kepala dengan Tinggi Badan Untuk Identifikasi Forensik. Jurnal e-Clinic. 2016;4

[27] Putri I. Korelasi Panjang Tulang Jari Telunjuk Tangan (Digiti II) Terhadap Tinggi Badan Pria Dewasa Suku Bali dan Suku Batak di Kecamatan Tanjung Senang Bandar Lampung. Fakultas Kedokteran Universitas Lampung. 2017.

[28] Rafki M, Hidayat IB, Aulia S. Classification Height and Weight of Human Footprint Using Discrete Cosine Transform (DCT) and Nearest Neighbor (NN) Method Based on Android. Bandung: Universitas Telkom. 2016.

[29] Rastogi P, Kanchan T, Menezes RG.Middle Finger Length-apredictorof Staturein The Indian Population. Med. Sci. Law. 2015:123-126.

[30] Rohen JW, Yokochi C, Drekoll EL, Chung KW. Color Atlas of Anatomy: A Photographic Study of Human Body. Seventh Ed. Lippincott William \& Wilkins; 2011.

[31] Simatupang ANH. Hubungan Panjang Telapak Tangan Terhadap Tinggi Badan pada Mahasiswa Fakultas Kedokteran Universitas Sumatera Utara Ibnu Sina Biomedika. 2017; Vol. 1.

[32] Snell RS. Anatomi Klinis Berdasarkan Sistem. (Suwahjo A, Liestyawan YA eds.). Jakarta:EGC;2011.

[33] Shah RK, Kanani SD, Patel BG, Tolani JN. Estimation of Stature from Head Length in Western Indian Gujarati Adolescent Population. Indian Journal of Anatomy and Physiology.2020.

[34] Suseelamma D, Gayathri P, Deepthi S, Chandra M, M UK, Amarnath. Study of Correlation between Stature and Length of Fingers. Scholars Journal of Applied Medical Sciences. 2014.

[35] Sulijaya C. Hubungan antara Tinggi Badan dengan Panjang Os Tibia Percutaneous pada Pria Dewasa Suku Jawa dan Suku Lampung di Desa Negeri Sakti Kabupaten Pesawaran. Bandar Lampung: Fakultas Kedokteran Universitas Lampung. 2013.

[36] Tanudjaja GN. Hubungan Tinggi Badan dengan Panjang Tangan pada Mahasiswa Fakultas Kedokteran Unsrat. Jurnal e-Biomedik. 2015;3(April).

[37] Tomuka J, Siwu J, Mallo JF, et al. Hubungan Panjang Telapak Kaki dengan Tinggi Badan untuk Identifikasi Forensik. Jurnal Kedokteran Unila. 2016. 
[38] Tortora G, Derrickson B. Principles of Anatomy and Physiology. 13th Ed. USA: John Wiley \& Sons Inc; 2011.

[39] Wibowo DS, Paryana W. Anatomi Tubuh Manusia. Singapore: Elsevier Ltd; 2009.

\section{AUTHORS}

First Author - Hendra Aprialdi Saputra, Department of Forensic and Medicolegal of Faculty of Medicin Universitas Sumatera Utara
Second Author - Alfred C. Satyo, Department of Forensic and Medicolegal of Faculty of Medicin Universitas Sumatera Utara Third Author - Abdul Gafar Parinduri, Department of Forensic and Medicolegal of Faculty of Medicin Universitas Sumatera Utara

Gmail : Hendraapriladisaputra@gmail.com 